\title{
DEVELOPMENT OF PROFESSIONAL COMMUNICATIVE COMPETENCE OF FUTURE LAWYERS IN THE PROCESS OF TEACHING ENGLISH
}

\author{
O. V. CHYZHYKOVA, PhD of Pedagogical Sciences, Associate Professor, \\ State University of Economics and Technology \\ E-mail: olgalehina@ukr.net \\ https://orcid.org/0000-0002-4432-9743
}

\begin{abstract}
Introduction. The article reveals the problem of developing the professional communicative competence of a future lawyer in the process of foreign language training as one of the most actual issues of higher education. Learner-centered and knowledge-centered learning environment of preparation of law students is underlined in the article. The author analyses different scientific approaches to the definition of professional communicative competence. This notion includes such components as speech skills and social-cultural set of knowledge both in language and in professional sphere and the ability to apply them effectively appropriately and creatively in practical professional legal situations.

The purpose of research is to analyze the main characteristics of professional communicative competence of future lawyer in the process of foreign language study and effective teaching methods of its development.

Results of research. The author exposes the effective teaching methods and technologies of law students' professional communicative competence development in the process of learning English as a foreign language. The article describes communication-based activities that promote active foreign language learning and develop communicative competence of future lawyers in the process of learning English. These activities are grouped into game-based activities, teacher-student and student-student interaction, discussions and debates. New techniques for ensuring law students' professional communicative competence development in the process of learning English on the basis of these types of activities are presented in the article. The course outline covers professional-oriented topics according to a particular area of law (Business Law, Health Care Law, Constitutional Law, Migration services, Environmental Law, Criminal Law, and Intellectual Property Law). A detailed description of communication-based practice for developing the professional communicative competence of future lawyers in the process of learning English is presented in this article.
\end{abstract}

Conclusion. Game-based, project-based and brainstorm activities, case studies, discussions have been established to be among the most effective means for future lawyers' professional communicative competence development.

Keywords: communicative competence, future lawyers, foreign language study, communication-based activities.

Introduction. The problem of formation and further development of professional communicative competence of future specialists, in the field of law in particular, has become one of the most essential issues of higher education. The globalization and integration world tendencies, changes in society, economics, technology, shift in contemporary higher educational system to learner-centered and knowledge-centered learning environment have influenced the process of preparation of law students.

Development of law students' communicative competence in the process of studying English as a foreign language in particular is an aim that learners and teachers strive to achieve. It should be noted that in legal profession communicative competence is of great importance, as it, firstly, determines the success of legal vocational activity, and moreover, people's life and society on the whole [5]. It is also a key to success in the legal profession, which identifies competitiveness for future lawyers on modern domestic and international labor market.

Analysis of recent researches. The problem of forming and mastering communicative competence of a future lawyer has paid attention of many scientists. Thus, A. Bochevar, S. Husarev, L. Nasilenko, O. Tykhomyrov analyzed the necessity of future lawyers' communicative competence formation in the process of professional training. Sabri T. S. Ahmed, Sunil V. Pawar, D. Demchenko, T. Maleyeva devoted their study to the problem of formation of foreign language communicative competence. Still, in spite of numerous scientific researches the problem of law students' professional communicative competence development in the process of foreign language learning has not been studied in its entirety.

The purpose of the article is to analyze the main characteristics of professional communicative competence of future lawyers and present practical implementation of communication-based activities for its 
development in the process of foreign language training.

The research methods: The following theoretical and practical methods of pedagogical research have been used in the article: theoretical analysis of scientific researches, methods of logical generalization, observation, interview and questioning.

Results and discussion. The profound analyses of scientific studies permit us to assert that "competence is understood as awareness and authority; integrated ability of the individual to perform activities successfully; deep knowledge of the subject; personal quality (set of qualities); integration of knowledge and skills, norms, emotional and value attitude and reflection; characteristics of education; educational results" [7, p. 88].

A professionally competent person is characterized as a specialist who has sufficient professional knowledge, abilities, professional interest, professional approach and professional attitude to work and is able to effectively implement professional activity and anticipate its consequences [7, p.89].

A specialist in the legal field is characterized by the following competences [6, 7]:

1. Psychological competences: cognitive, volitional and emotional, perceptual, and mnemonic.

2. Personal competences: intellectual abilities (mind, logic, originality, prudence); personal traits (initiative, honesty, integrity, confidence, independence, energy, selforganization); reflection; creativity (readiness for quick mastering of new forms of work, willingness to find out new effective ways of performing the usual types of activities; flexibility, novelty, curiosity).

3. Social competencies: social psychology; willingness to cooperate; interact with the surroundings; emotional intelligence and responsibility.

4. Professional and managerial competencies: knowledge of the regulatory framework governing activities; knowledge of managerial and technological aspects of legal activity; knowledge and skills of basic control methods and effective business communication [7].

5. Practice skills (both professional skills, such as identifying existing problems in legal services, knowledge of current system of law and legal service, and interpersonal skills, including emotional intelligence, ability to work in a teamwork and collaboration), business skills (accounting and finance), legal project management, internationalization and crossborder practice of law, inter-disciplinary experience, and resilience [6].

Along with other professional competences (personal-motivational competence, practical activity competence, special competence, professionally legal competence, personal competence, psychological competence, sociopsychological competence, socio-perceptual competence etc.) communicative competence takes a special place in professional activities of a lawyer [4, 7, 8].

Communicative competence is related to the knowledge of the language and the ability to implement this knowledge in practical situations to meet communication needs [1, p. 302]. Communicative competence is defined as a system of knowledge, language and nonlanguage skills; a set of internal resources, necessary to build effective communication; the ability to perform productive tasks in the process of communication and interpersonal interaction [7, p.94]. It also can be defined as knowing linguistic and non-linguistic communication rules and the ability to implement it effectively and appropriately in communicative situations in order to reach communicative objectives [1, p. 304]; as a particular level of language skills, speech, social and cultural knowledge, skills and abilities, which make it possible to vary reasonably person's communicative behavior according to the functional predictors of foreign language communication and to build the ground for the qualified activities in different professional areas [3, p. 150]. D. Demchenko and T. Maleyeva rightly underlined that communicative competence is an indispensable part of professional competence of a lawyer that comprises knowledge of linguistic means, speech skills and abilities, which allow a lawyer to perform interaction and communication effectively, to work with various legal documents, to use reasonably language and speech means for fulfilling special tasks and terms of communication [5, p. 269]. Thus, communicative competence of a future lawyer in the process of learning English includes such components as speech skills of a foreign language, social and cultural knowledge of a foreign language (English) and knowledge in legal vocational sphere and the ability to apply it effectively, appropriately and creatively in practical professional legal situations to perform professional tasks.

It also includes the ability to determine the persuasiveness of the arguments in the assessment of previously unknown conditions and circumstances; to synthesize the relevant concepts in the context of the analyzed problem and demonstrate their own vision of ways of its solution; to formulate professional judgments based on the analysis of a known problem; to evaluate the disadvantages and advantages of arguments by analyzing a problem; provide advice on possible ways to protect the rights and interests of clients in different legal situations.

Communicative competence is also defined 
Issues in theory and methods of teaching foreign languages.

Проблеми теорії і методики навчання іноземних мов

as the integrative resource of an individual that provides successful communicative activity. It contains not only those components that can be measured by language testing, but also other personal properties such as the general level of intelligence, the general worldview, system of the interpersonal relationships, special professional knowledge, potential for personal development in mastering a foreign language [2].

Communicative competence includes: grammatical competence (knowledge of lexical units, grammar rules and structures, language rules in phonetics, morphology, syntax, phonology); sociolinguistic (sociocultural regulations of language usage); strategic competence (communication strategies that are able to compensate drawbacks in communication); discourse competence (skills of combination of language functions and structures into a coherent text); macro skills of a language (skills of speaking, writing, listening, and reading) [1].

Among practices that promote active foreign language learning can be used communication-based and task-based activities. These types of foreign communication practice play an essential role in communicative competence development compared with reproductive learning strategies that are aimed at imitating, memorizing and repeating and which focus on a particular language structure as a substitute of (instead of) the appropriate language use [1].

In our research we designed and successfully implemented a course outline for developing the professional communicative competence of future lawyers in the process of learning English. It is based on communicative activities and may be modified and altered.

Table 1

Communication-based activities for developing the professional communicative competence of future lawyers in the process of learning English

\begin{tabular}{|c|c|c|c|}
\hline Areas of Law & Topics & $\begin{array}{l}\text { Year } \\
\text { of } \quad \text { study }\end{array}$ & Types of Communication-based practice \\
\hline Business Law & $\begin{array}{l}\text { Small-business law } \\
\text { Corporate law }\end{array}$ & 1 & $\begin{array}{l}\text { Interview "How to start business in the USA: legal } \\
\text { aspects" } \\
\text { Project "Starting your business: legal aspects" } \\
\text { Brainstorm activity: studying legal peculiarities of } \\
\text { different forms of business (sole proprietorship, } \\
\text { partnership, corporation), working with legal } \\
\text { documents (contract, agreement). }\end{array}$ \\
\hline Health Care Law & $\begin{array}{l}\text { Heath laws and } \\
\text { regulations on insurance } \\
\text { medicine } \\
\text { Medical malpractice }\end{array}$ & 1 & $\begin{array}{l}\text { Data analysis on the topic upon medical fraud } \\
\text { Small group discussions "How to increase the number } \\
\text { of blood donors: legal aspects" } \\
\text { Writing a letter of complaint }\end{array}$ \\
\hline Constitutional Law & $\begin{array}{l}\text { Principles enshrined in } \\
\text { the Constitution } \\
\text { Individual rights vested } \\
\text { by the constitution }\end{array}$ & 1 & $\begin{array}{l}\text { Oxford debates on the inherent powers of a state } \\
\text { (branches of government, separation of powers) } \\
\text { Constitutional law conference (Women's rights) }\end{array}$ \\
\hline Migration services & $\begin{array}{l}\text { Documents for visa } \\
\text { regulations, instructions } \\
\text { to get immigration permit }\end{array}$ & 1 & $\begin{array}{l}\text { An interview "How to get a Visa" } \\
\text { gathering information on the topic "Irregular migration" }\end{array}$ \\
\hline Environmental Law & $\begin{array}{l}\text { Pollution control } \\
\text { Climate change }\end{array}$ & 2 & $\begin{array}{l}\text { Case study "A claim against a plant because of } \\
\text { emission of air pollutants into the atmosphere" } \\
\text { Project on Environmental Law Making in Ukraine } \\
\text { Survey "Climate change risks and climate litigation" }\end{array}$ \\
\hline Criminal Law & $\begin{array}{l}\text { Crime and punishments } \\
\text { Types of offences } \\
\text { Types of evidence }\end{array}$ & 2 & $\begin{array}{l}\text { Expressing opinions "Death penalty (pro and cons)" } \\
\text { Student project "Witness Protection in Ukraine" } \\
\text { Simulation "The Crane case" } \\
\text { Storytelling activity "At the customs (drug smuggling)" }\end{array}$ \\
\hline $\begin{array}{l}\text { Intellectual Property } \\
\text { Law }\end{array}$ & $\begin{array}{l}\text { Patent law } \\
\text { Trademark law } \\
\text { Copyright law }\end{array}$ & 2 & $\begin{array}{l}\text { Listening "An interview with a client" } \\
\text { Devising a more efficient way to protect intellectual } \\
\text { property } \\
\text { Dialogues "In a courtroom" }\end{array}$ \\
\hline
\end{tabular}

The course outline covers a number of topics from different areas of law and communication-based practice for developing the professional communicative competence of future lawyers in the process of learning English for firstand second-year law students. In our research we 
summed up some activities, based on the researchers' studies in teaching English as a foreign language, observation, interview and questioning and teaching experience, which promote developing law students' communicative competence. Thus, we used such activities as:

Game-based activities (simulation and roleplays) are considered to be an effective tool for developing law students' communicative competence. Such activities proved to be effective in developing communicative competence of future lawyers while learning English and turn the process of language acquisition into interesting and interactive activities [1]. Law students are involved in practical language situation from professional field in particular. Learners develop their creative potential, reproducing a certain trial (from a real life or composed), fulfilling the roles of a judge, a prosecutor, a victim, an eye-witness or a defender etc.

Teacher-student and student-student interaction stimulates law students' motivation for learning foreign languages. In this case a teacher performs a role of a facilitator and co-creator and students are active participants of the learning process. They also act as knowledge builders, problem solvers and reflexive learners in different types of activities. These types of practice usually include active group work, brainstorming, and dialogue, where students are encouraged to converse in pairs and groups, cultivate their communicative competence and self-confidence

\section{References}

1. Ahmed, S., Pawar, S. (2018). Communicative Competence in English as a Foreign Language: Its Meaning and the Pedagogical Considerations for its Development. The Creative Launcher, Vol. II, Issue VI, 301-312. URL: https://www.researchgate. net/publication/324392820_Communicative_Compet ence_in_English_as_a_Foreign_Language_Its_Mean ing_and_the_Pedagogical_Considerations_for_its_D evelopment

2. Baytucaeva, A., Bissenbayeva, Zh., Baytukaeva, D., Uaidullakyzy, E., Mukasheva, S. (2013). Modern Approaches in Professional Communicative Competence Formation. Procedia Social and Behavioral Sciences, 89, 710-714. DOI: 10.1016/j.sbspro.2013.08.919

3. Belousova, V. V. (2018). Formation of communicative competence of future lawyers in higher education. "Social and Humanitarian Bulletin", 18-19, $150 . \quad$ URL: http://nbuv.gov.ua/ UJRN/sochumj_2018_18-19_42

4. Bochevar, A. (2016). State of Future Lawyers' Informative and Communicative Competence Maturity. Science and education, 1, 510. https://doi.org/10.24195/2414-4665-2016-1-3

5. Demchenko, D., Maleyeva, T. (2018). and have more opportunities for exposure.

Discussions and debates increase law students' linguistic competence and form selfefficiency. Students are encouraged to express their personal opinion, develop professionally-oriented communication skills and the ability to apply creatively language material based on professional knowledge; stimulate critical thinking etc.

Conclusion. The development of communicative competence of law students is one of the important tasks of higher legal education. Professional communicative competence of future lawyers can be defined as the knowledge of language rules and the skills to use this knowledge and speech means appropriately and creatively in practical situations in professional legal sphere. Such competence includes various aspects of language such as sociolinguistic, grammatical, strategic, discourse competences and language macro skills etc. Communicationbased activities including game-based activities, teacher-student and student-student interaction, discussions and debates can be successfully implemented and used for developing the professional communicative competence of future lawyers in the process of learning English.

Prospects for further research are related to the analysis of information and communication technology in the development of communicative abilities of students of non-linguistic specialties in the process of learning foreign languages.

Formation of professional foreign language competence of the future lawyer. Oleksandr Dovzhenko Hlukhiv National Pedagogical University Bulletin. Series: Pedagogical sciences, 38, 268-274.

6. Legg, M. (2018). New Skills for New Lawyers: Responding to Technology and Practice Developments. The Future of Australian Legal Education (Thomson Reuters 2018), UNSW Law Research, No. 18-51. URL: https://ssrn.com/ abstract $=3235075$

7. Mudryk, A., Kykhtuik, O. (2020). Professional Competence of a Lawyer. Psychological Prospects Journal, 35, 83-100. DOI: https://doi.org/10.29038/2227-1376-2020-35-83-100

8. Nasilenko, L. (2014). Forming the Future Lawyers' Communicative Competence: The Experience of Higher Education in Ukraine and Germany. Comparative Professional Pedagogy, 4 (3), 89-94. DOI: 10.2478/rpp-2014-0041. 
Issues in theory and methods of teaching foreign languages.

Проблеми теорії і методики навчання іноземних мов

\section{РОЗВИТОК ПРОФЕСІЙНОЇ КОМУНІКАЦІЙНОЇ КОМПЕТЕНТНОСТІ МАЙБУТНІХ ЮРИСТІВ В ПРОЦЕСІ ВИКЛАДАННЯ АНГЛІЙСЬКОЇ МОВИ}

\section{О. В. Чижикова}

Анотація. Актуальність дослідження полягає у висвітленні сучасних методів формування $i$ подальшого розвитку профресійної комунікативної компетентності майбутніх юристів в процесі вивчення англійської мови. У статmі розкрито різні підходи до визначення профресійної комунікативної компетентності. Профресійна комунікативна компетентність майбутніх юристів охоплює знання мовних правил та мовленнєвих навичок ефективного й належного використання цих знань, умінь та мовних засобів у профресійній юридичній сфрері. Така компетентність включає різні аспекти мови, такі як соціолінгвістична, граматична, стратегічна, дискурсивна компетенції, та мовленнєві навички макрорівня. Таким чином, комунікативна компетентність майбутніх юристів у процесі вивчення англійської мови включає такі компоненти, як іншомовні мовленнєві навички та сукупність соціально-культурних знань як з іноземної мови, так і в профресійній сфрері, а також здатність ефрективно, доречно та креативно застосовувати їх у практичній профресійній юридичній діяльності.

Мета статmі - проаналізувати основні фрактори професійної комунікативної компетентності майбутніх правознавців та представити практичну реалізацію програми ії розвитку на основі сучасних видів комунікативної діяльності у процесі оволодіння іноземною мовою профресійного спрямування.

Результати дослідження: у статті розкрито ефективні шляхи розвитку профресійної комунікативної компетентності майбутніх юристів у процесі вивчення анелійської мови як іноземної. Автором розроблено детальну фракультативну програму розвитку професійної комунікативної компетентності майбутніх правознавців у процесі вивчення англійської мови на основі сучасних інтерактивних видів комунікативної діяльності. Програма охоплює професійноорієнтовані теми відповідно до певної галузі права (Підприємницьке право, Конституційне право, Міграційне право, Екологічне право, Кримінальне право та Право інтелектуальної власності). В статті представлено детальний опис сучасних видів комунікативної іншомовної діяльності майбутніх юристів у процесі вивчення англійської мови. Кожен вид комунікативної діяльності розроблено до певної теми.

Висновки. Найбільш ефрективними методами розвитку профресійної комунікативної компетентності у процесі оволодіння іноземною мовою $є$ метод проектів, дискусії і дебати, симуляції.

Перспективи подальших розвідок пов'язані із аналізом інфрормаційних технологій у розвитку комунікативних здібностей студентів нефрілологічних спеціальностей у процесі вивчення іноземних мов.

Ключові слова: комунікативна компетентність, майбутні правознавці, вивчення іноземних мов, вища освіта, комунікативна діяльність. 